\title{
Representativeness of women in postgraduate programs in computer science in Brazil
}

\author{
Douglas Farias Cordeiro ${ }^{1}$, Anelise Souza Rocha ${ }^{1}$, \\ Kátia Kelvis Cassiano ${ }^{1}$, Núbia Rosa da Silva ${ }^{2}$ \\ ${ }^{1}$ Faculdade de Informação e Comunicação - Universidade Federal de Goiás \\ Campus Samambia, 74.690-900, Goiânia - Brazil \\ ${ }^{2}$ Instituto de Biotecnologia - Universidade Federal de Goiás \\ Av. Dr Lamartine P. de Avelar, 1120, 75.704-020, Catalão- Brazil \\ cordeiro@ufg.br, anelisesrocha@gmail.com, \{katiakelvis, nubia\}@ufg.br
}

\begin{abstract}
From the patriarchal gender culture, inequities emerge that are manifested in social and labor relations. Women still lead to disparities in participation and production of a scientific nature around the world, being more evident in technological areas. This paper presents an exploratory descriptive analysis of postgraduate teaching in Computer Science in Brazil, addressing aspects of representativeness by gender in that area. The results revealed that, despite the programs to encourage the participation of women in the areas of technology, in the last 15 years there has been a significant reduction in the proportionality of women in postgraduate teaching in Computer Science in Brazil. In addition, it opens discussions on issues of interest related to factors such as the predominant age group of women in the area, 40-69 years, suggesting research on the impact of other factors on active participation, such as motherhood, for example.
\end{abstract}

Resumo. Da cultura patriarcal de gênero emergem iniquidades que se manifestam nas relações sociais e trabalhistas. As mulheres ainda protagonizam disparidades na participação e produção de cunho científico em todo o mundo, sendo mais evidente em áreas tecnológicas. Este artigo apresenta uma análise descritiva exploratória da docência de pós-graduação em Ciência da Computação no Brasil, tratando aspectos da representatividade por gênero naquela área. Os resultados revelaram que, apesar dos programas de incentivo à participação das mulheres nas áreas de tecnologia, nos últimos 15 anos houve uma redução significativa na proporcionalidade de mulheres na docência de pós-graduação em Ciência da Computação no Brasil. Além disso, a faixa etária predominante de mulheres na área é de 40-69 anos, sugerindo uma investigação sobre o impacto de outros fatores na participação ativa como a maternidade, por exemplo.

\section{Introduction}

There are countless movements, actions and projects aimed at seeking and guaranteeing gender equality, crossing social rights, civilian politics, and financial issues. Studies related to women's participation in society had an initial focus on the historical regeneration of groups hitherto excluded from the narratives of Western civilization. Through the strengthening of feminist theory, historians began to find evidence of experiences linked 
to women who contributed effectively to social history [Scott 1990]. The study and sharing of such experiences offered support for the visibility of female participation in the different sectors that make up a society, being a mechanism for generating information about the works and actions developed by women.

Historically, education has been considered a field of male activity and, although some women have participated significantly in its development, for a long time they did not have due recognition. The academic environment and associated practices were designed and shaped according to male characteristics and specificities, with knowledge generated and directed to men [Louro 2004]. From the moment that there was a social mobilization in favor of the education of women, there was a need for the presence of women teachers, providing a feminization of teaching.

The possibilities generated by the participation of women in education revealed that their average schooling goes beyond the schooling of men. According to [ONU 2018], women study an average of 8.2 years, while men study 7.8 years. The education of women can be described as an action to transform society, which corroborates to the insertion of women into the labor market. Between 1976 and 2007, for example, women's participation in the labor market grew by $85 \%$, while men's participation grew by $28.1 \%$ [Araújo and Facchini 2018].

With the expansion of education in the second half of the 20th century, and the beginning of the 21 st century, women began to work in different areas, even in those considered more masculine within the sciences, such as the exact sciences, engineering and technologies. Despite this, quantitatively, in Brazil the number of women in scientific research is still lower than the number of men. This article presents a study on the participation of women in higher education, specifically in postgraduate teaching in Computer Science, through an exploratory analysis of a historical series from 2004 to 2018, also addressing aspects such as age and theoretical distribution. The results show the delicate situation of female representation in the area, which has proportionally decreased over the years, generating input for discussions and reflections on the need to promote and implement policies to encourage equity between men and women in science in Brazil, and specifically in Computer Science.

\section{Women and science}

The movements to guarantee equality, visibility and empowerment of women provide a constant increase in the discussion about women and science. In this sense, the epistemological evolution of science is marked by the breaking of paradigms and truths [Francelin 2004]. Along with the emergence of modern science, there is a tendency to objectify women, where they are denied the capacity and authority of knowledge in relation to not meeting emancipatory needs [Sardenberg 2002]. However, studies reveal that the second half of the 20th century is marked by an advance in women's access to science, with a progressive increase in their participation, which is still linked indirectly to movements that fight for gender equality, and social, political and economic transformations [Citeli 2000, Schienbinger 2001, Nuemberg 2005].

The discussion about women and science has a strong relationship with the feminist movement from the Feminist Studies of Science and Technology (EFCT), which articulates science and gender questions [Matheis 2016]. In this sense, it is worth men- 
tioning that feminism emerged as an intellectual project, culminating in a feminist theory [Keller 2006], which led to a search for knowledge and recognition of women in science [Schienbinger 2001].

According to [Schienbinger 2001], during the 17th and 18th centuries, the exclusion of women was not considered an inevitable fact, since a series of scientific works allowed access to women. However, despite this scenario of prior inclusion, there were rare episodes in which merit was associated with a woman. In Brazil, although in 1832 the Faculty of Medicine of Rio de Janeiro created the course for midwives, it was only in 1879 that the right and freedom for women to study and obtain a higher academic degree was established [Lopes 1998].

Until the beginning of the 19th century, women from the highest social classes were known to be great ladies who engaged in letter writing, marriage, children and social conventions [Woolf 2018]. The main insertions of women in intellectual works were restricted to writing. [Freitas and Luz 2017] emphasize that the idea that scientific development is linked to men, who would not be interested in activities of a family or domestic nature, is still strongly dedicated to their research.

Despite the right of access to higher education, the Brazilian educational reality of the 19th century and the first half of the 20th century ended up making this unfeasible and restricted, since most of the secondary education courses had restrictions to the women [Beltrão and Diniz 2009]. On the other hand, despite this unfavorable scenario, which was commonly justified by a movement to naturalize the differences between men and women due to their biological characteristics, or even from a cultural perspective, women continually sought their presence and space in the scientific development [Silva 2012].

The consolidation of the conquest of women in the labor market is associated with the needs of capitalism, which, based on economical and labor demands, opened space for the emergence of paid work for women [Olinto 2011]. Along with this, there were several perspectives and socio-cultural paradigms imputed towards the establishment of stereotypes and skills related to men and women, which were established as barriers and limits in accessing certain opportunities and positions [Fraga and de Oliveira 2020].

The labor limitation of women is conceptualized through horizontal and vertical segregation [Olinto 2011], where in the horizontal segregation, women are strained to follow paths that diverge from those followed by men, and in the vertical segregation, women are placed in positions of subordination or still do not progress professionally due to existing social mechanisms. In the scope of science, this phenomenon is called as a scissor effect [Barbosa and Lima 2013], where there is a disproportionate decrease in the number of women according to the advancement in the scientific career. In this sense, 2017 data from INEP (National Institute of Educational Studies and Research Anísio Teixeira) reveal that although women are the majority in the teaching of early grades, in the academic career they become a minority [INEP 2017]. In the context of computer science, this scenario is even more divergent, as presented in the results of this paper.

\section{Women in computer science}

Inequalities resulting from a patriarchal gender culture are manifested by different means in social and labor relations [Garcia and Duarte 2017]. The science is no exception, 
women represent a minority of researchers worldwide and lead to disparities both in participation and in the production of scientific nature.

The results presented in [ELSEVIER 2017], in which 27 areas of knowledge are considered, and over a period of twenty years, between 1996 and 2015, gender equality among effectively active scientific researchers is reaching a level of balance. However, despite this, the growth rate in the number of women is just over $8 \%$ for the analyzed period, which is highlighted as lower than the reported expectations. Brazil and Portugal are the countries with the greatest expression, with $49 \%$ of women, while Japan has $20 \%$ of active researchers. In the context of Brazil, specifically considering computer science, female representativeness drops to $23 \%$, still having a projection of inexpressible temporal analysis. As a comparison parameter, in the health area the female percentage rises to $48 \%$.

According to [ELSEVIER 2017], the disparity in female inclusion in the research is not directly related to the type of economy or development of countries. Japan is a reference in technology and research in the world and has less representation of women than the other countries evaluated, which have an average of $42 \%$, among them, USA, Canada and the United Kingdom, in addition to developing countries such as Chile, Mexico and Brazil. [Agarwal et al. 2016] claim that the gender imbalance in research is not related to developing countries, and in addition, there is a non-standard variation in the participation of women in technology research, being peculiar to each country's cultural, economic and social characteristics.

The temporal rise of women in research is not a reflection in all areas of knowledge, nor in all countries. However, cultural deconstruction and incentive policies can produce good results of gender equity in areas with a male predominance. Carnegie Mellon University (CMU) was successful in proposing a cultural change in support of women studying computer science, giving them representation, stimulating the creation of a group of women, placing them as a spokesperson for the university in the face of future students, in addition to removing specific prerequisites for admission, tripling the number of women enrolled in eight years [Frieze and Quesenberry 2019].

These female conglomerates in computing and technology have a significant history in the evolution of equality, such as the Anita Borg Institute (ABI - since 1987) and the Association for Computing Machinery - Women, organizations committed to the equalization of rights and representation. According to [DuBow et al. 2016], Dr. Anita Borg predicted to achieve what she calls 50/50 women and men in computer science in 2020. ABI ratified this data, extending the deadline to 2025 and also bringing up the question of equal pay as goal. Despite representation, incentives and expectations, this equality still remains distant and under construction, below expectations.

In this context, the Women in Science program, launched in Brazil by the British Council ${ }^{1}$, stands out. The aim of the program is to encourage female participation in science, technology, engineering and mathematics from elementary school, so that, at the university, they can follow their interests in these areas.

In Brazil, several public policies implemented in the last decade aimed at pro-

\footnotetext{
${ }^{1}$ The British Council is an international organization in the United Kingdom that aims to strengthen cultural relations and enhance educational opportunities.
} 
moting gender equity have contributed to female participation in science: the Woman and Science Program, launched in 2005 by the Secretariat for the Promotion of Women in partnership with the National Council for Scientific Development and Technological (CNPq) and several bodies related to Education, Science and Technology, encouraged female participation in academic careers and promoted research projects of gender studies.

In addition, the Brazilian National Education Plan, proposed in 2010, defined actions to be carried out in the period 2011-2020 to eradicate historical discrimination and abolish gender stereotypes, representing a milestone in fostering female participation in the Brazilian scientific community. It can be seen that, in general, Brazil stands out in terms of gender equity in research, but is considerably below in the scope of computer science. According to a study carried out at the Federal University of Paraíba, there was a decline in enrollment of women in 32 years of the computer science course, with a drop of $0.4 \%$ per year [Moreira et al. 2018].

In this projection, the trend is that in 2050 there will be no women enrolled in the course of that institution of higher education. According to [Moreira et al. 2018], the bottleneck is found in entering universities, that is, the work to be done has to start in basic education, through actions that promote the presentation and the encouragement of female participation in technological research, once that the increase in the number of researchers is directly related to entry into undergraduate courses, thus making it the first obstacle faced for gender equity in computer science.

\section{Metodology}

The main objective of this paper is to carry out an analysis about the equity between men and women in the postgraduate teaching in computer science in Brazil. For this purpose, a dataset was extracted from the Capes Open Data Portal ${ }^{2}$. For data analysis, the attributes related to the questions of interest to be answered were considered, which included: reference year, area of knowledge, educational entity, region, gender and age group. The dataset obtained resulted in more than 2.1 billion records, distributed over a 15-year historical series (2004-2018).

Data treatments were performed to detect possible anomalies or errors. In addition, an equivalence was made in the labels of the attributes of the dataset, since they do not have a naming pattern, that is, certain attributes have different names in different years. Data processing was performed by building a solution in Python programming language, using routines from the Pandas and Numpy libraries.

The treated data were integrated into a structured dataset, in CSV format (comma separated values). This format was chosen due to its advantages in terms of data manipulation [Fernandes and Cordeiro 2016]. The descriptive analysis stage was performed using BI (Business Intelligence) software, in which normalizations, crossings and visualization of the data of interest were built. The results were generated in order to assertively demonstrate the representation of women in the area considered. Therefore, all analyzes were performed separately for each gender.

\footnotetext{
${ }^{2}$ https://dadosabertos.capes.gov.br/.
} 


\section{Results}

According to analyzes carried out by [ELSEVIER 2017], there are still notable differences between the number of women and men in the technology area. In this sense, the first analysis carried out in this paper sought to measure the distribution of men and women professors in postgraduate programs in Brazil, considering all areas of knowledge (Figure 1). Numerically, the number of men is considerably greater than the number of women, however it is interesting to note that the average annual growth for the analyzed period was $6.05 \%$ for men and $8.04 \%$ for women. Considering the analyzed period, the total growth was $140.0 \%$ for men, and $193.3 \%$ for women.

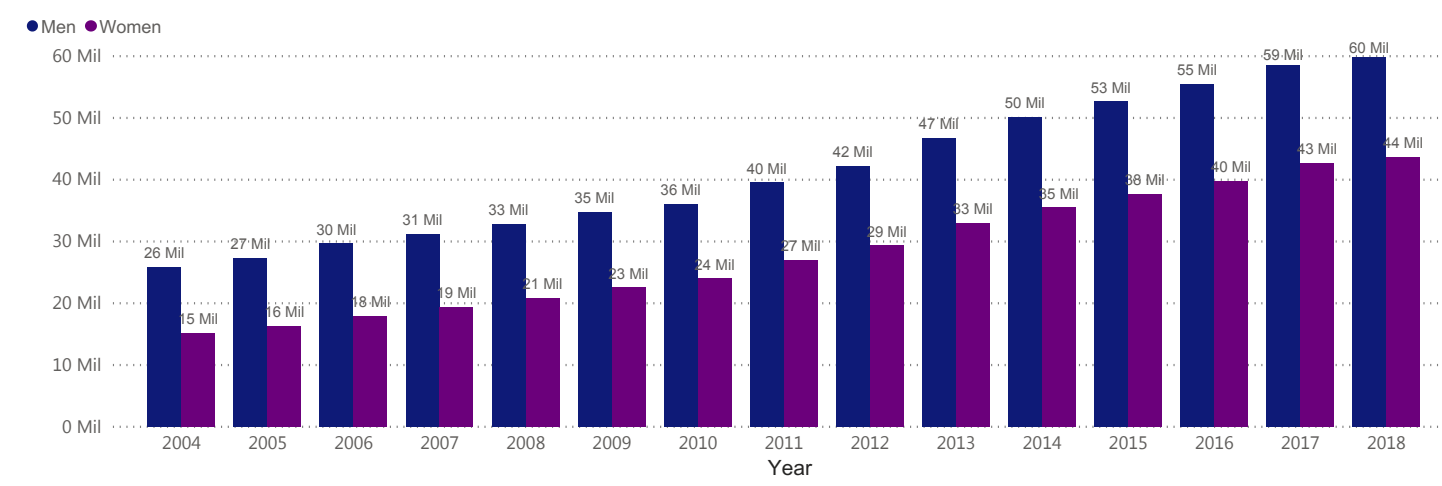

Figure 1. Temporal distribution of professors in postgraduate teaching for all areas of knowledge.

For the computer science area there is also a significant difference between the number of men and women (Figure 2). However, the average annual growth rate is higher for men $(7.20 \%$ per year) than for women $(6.07 \%$ per year). If only the last five years of the time series (2014-2018) are considered, this discrepancy becomes even greater, with the average percentage growth of $3.68 \%$ per year for men, and $1.39 \%$ per year for women. For the total period, the growth in the number of men was $159.61 \%$, while the growth of women was $123.24 \%$. Considering the last five years, the growth in the number of men in computer science was $11.03 \%$, while the growth of women was $0.98 \%$, which represents a quantitative increase of four women.

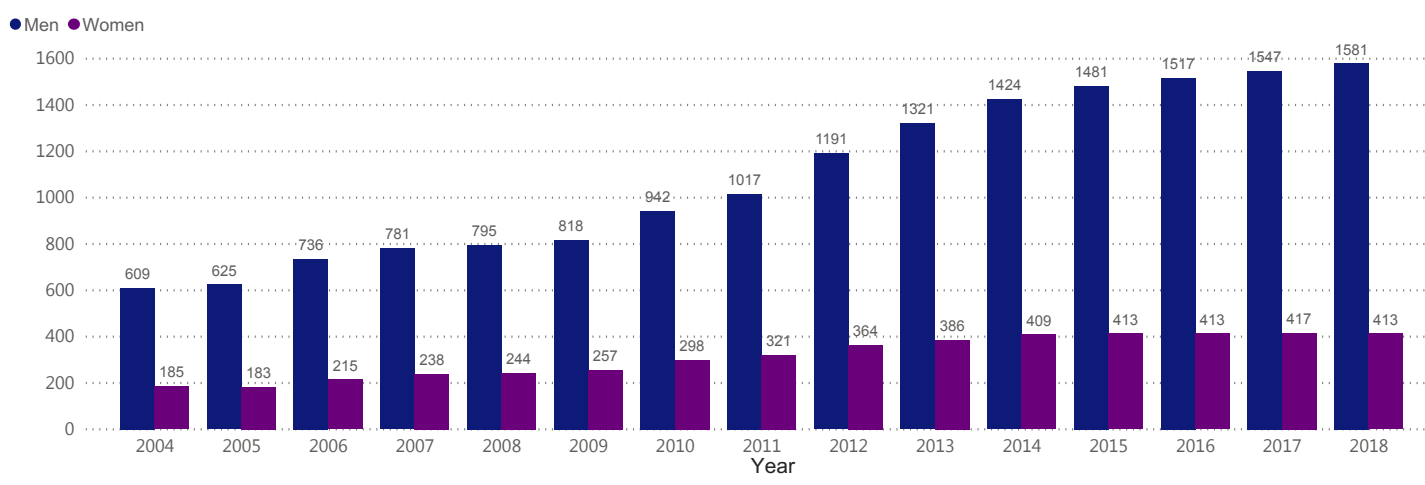

Figure 2. Temporal distribution of professors in postgraduate teaching in computer science.

The inequity between men and women in the computer science area is even more visible when analyzed in terms of proportionality in terms of total distribution, consid- 
ering all areas. Figure 3 shows the proportional variation curves over the analyzed historical series. It is possible to observe that initially men in computer science represented $2.35 \%$ of the total number of men, rising to a percentage of $2.64 \%$ in 2018 . On the other hand, women who had a representation of $1.22 \%$ at the beginning of the historical series, dropped to $0.95 \%$ in 2018.

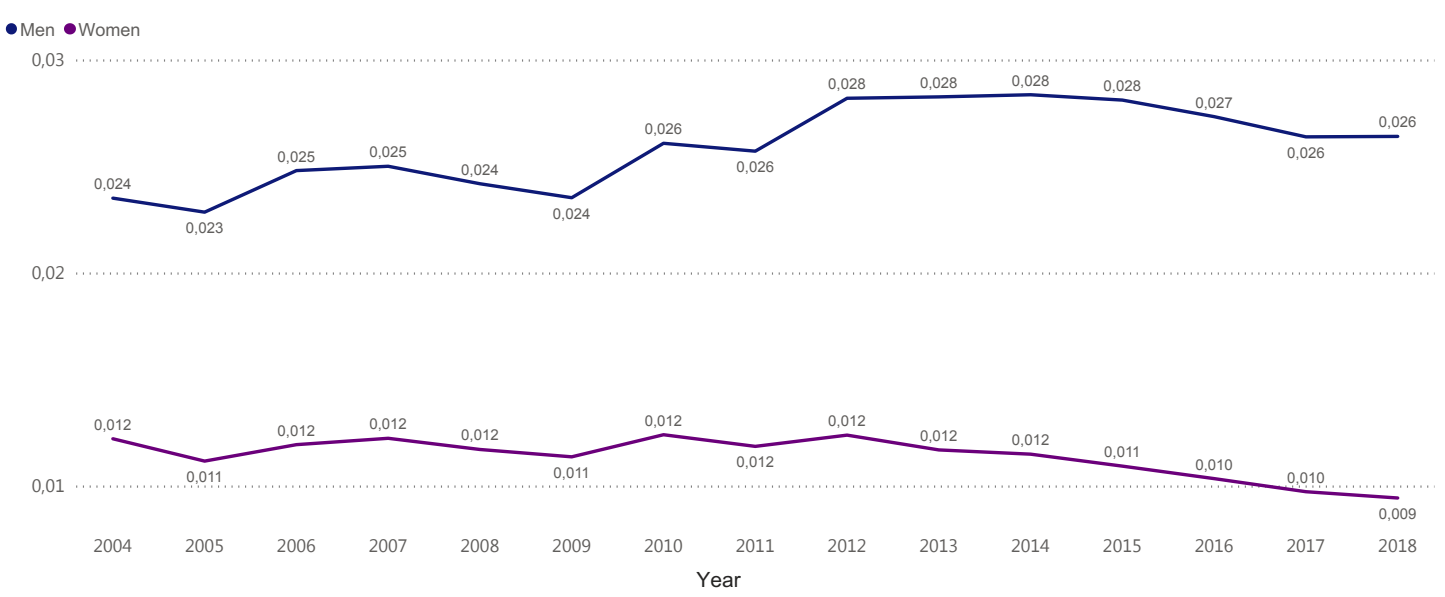

Figure 3. Proportionality between computer science professors and professors from all areas.

Some interesting aspects related to the distribution of men and women must still be considered: the age and the region where the educational institution is located. Figure 4 shows the age distribution. It is possible to note that, in percentage, the proportional number of women in the age groups above 40 years and below 69 years is higher. However, for ages under 40, the proportionality of men is considerably higher than that of women. This fact draws attention because it is a possible indicator of a drop in the proportion of men and women for the coming years, considering the possibility of retirement by woman professors.

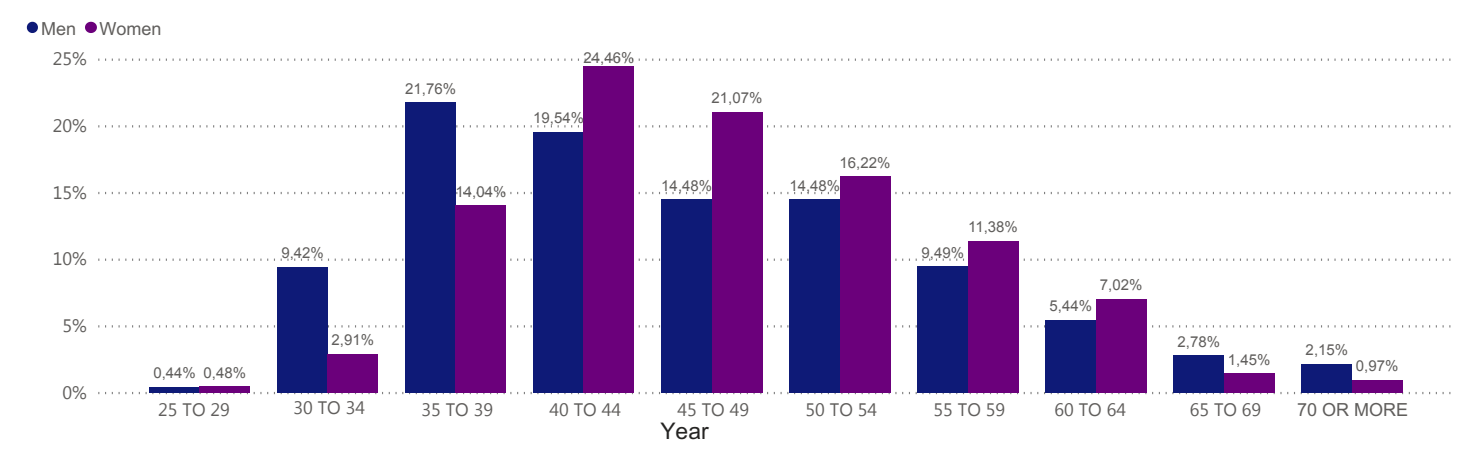

Figure 4. Proportional distribution by age and gender.

In terms of the greographic region, the proportional concentration of women is higher for the Brazilian South and Southeast regions, while for the Northeast and North regions the proportional predominance is of men (Figure 5). It is important to highlight that in terms of number of individuals, all regions have a greater number of men than women, and the analysis presented is proportional in terms of the distribution of each 
gender. Differences in distribution may be linked to a stronger patriarchal culture in the North and Northeast regions of the country.

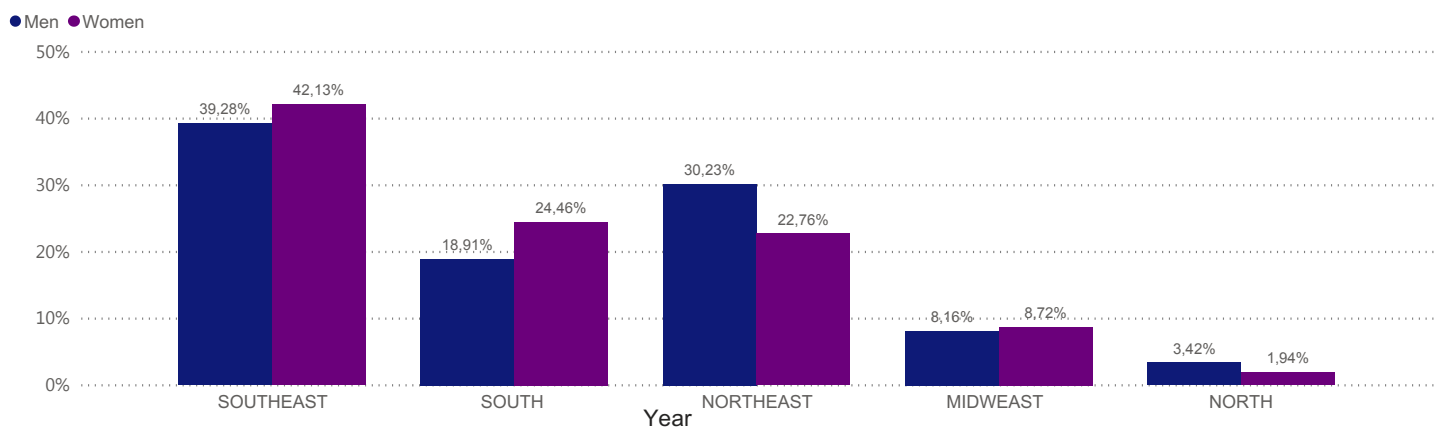

Figure 5. Proportional distribution by region and gender.

\section{Conclusion}

Cultural aspects, such as patriarchy, give women a condition of accumulating socially standardized functions, as the holder of the responsibilities of the home and children, in addition to the social demand and personal fulfillment, in having professional success. Interdisciplinary studies related to the theme "women in computer science" have revealed information that fosters the definition and development of policies to encourage participation and production in the scientific field. However, the role of women in research in general goes through important cultural obstacles that determine their performance and representation.

Patriarchal creation, the social division of gender inserted in various areas of knowledge, imposes a pre-established path for women, which can be one of the first barriers to the entry of women in computer science. In addition, their permanence and contribution to research are compromised when one more issue is considered, motherhood. The picture of this scenario of inequality between men and women in the teaching of postgraduate studies in computer science is remarkable. Although there are several initiatives aimed at the insertion and participation of women in this area, there are still several obstacles to overcome, which cross the limits of science. Anyway, the results presented in this paper are important indicators for the development of studies oriented to the insertion of women in computer science, in order to understand the experiences, difficulties and challenges of women in teaching in this area, and to generate strategic information for the promotion of gender equality.

\section{References}

Agarwal, S., Mittal, N., Katyal, R., Sureka, A., and Correa, D. (2016). Women in computer science research. ACM Computers \& Society, 46(1):7-19.

Araújo, A. M. C. and Facchini, R. (2018). Mulheres e direitos humanos no brasil: avanços e desafios. Jornal da Unicamp. Online: https://www.unicamp.br/unicamp/ju/artigos/direitos-humanos/mulheres-e-direitoshumanos-no-brasil-avancos-e-desafios. 
Barbosa, M. C. and Lima, B. S. (2013). Mulheres na física do brasil: Por que tão poucas? e por que tão devagar? In Yannoulas, S. C., editor, Trabalhadoras: análise da feminização das profissões e ocupações. Editorial Abaré, Brasília, DF, Brazil.

Beltrão, K. I. and Diniz, J. E. (2009). A reversão do hiato de gênero na educação brasileira no século xx. Cadernos de Pesquisa, 39(136):125-156.

Citeli, M. T. (2000). Mulheres nas ciências: mapeando campos de estudos. Cadernos Pagu, (15):39-75.

DuBow, W. M., Quinn, B. A., Townsend, G. C., Robinson, R., and Barr, V. (2016). Efforts to make computer science more inclusive of women. ACM Inroads, 7(4):74-80.

ELSEVIER (2017). Gender in the global research landscape. Online. https://www.elsevier.com/research-intelligence/campaigns/gender-17.

Fernandes, J. L. F. and Cordeiro, D. F. (2016). Avaliação de formatos de publicação de dados abertos governamentais através de indicadores de usabilidade. Tendências da Pesquisa Brasileira em Ciência da Informação, 9(1):65-83.

Fraga, A. and de Oliveira, S. R. (2020). Mobilidades no labirinto: tensionando as fronteiras nas carreiras de mulheres. Cadernos EBAPE.BR, 0(0):1-21.

Francelin, M. M. (2004). Ciência, senso comum e revoluções científicas: ressonâncias e paradoxos. Ci. Inf., 33(3):26-34.

Freitas, L. B. and Luz, N. S. (2017). Gênero, ciência e tecnologia: estado da arte a partir de periódicos de gênero. Cadernos Pagu, (49):e174908.

Frieze, C. and Quesenberry, J. L. (2019). How computer science at cmu is attracting and retaining women. Communications of the ACM, 62(2):23-26.

Garcia, L. P. and Duarte, E. (2017). Equidade de sexo e gênero na pesquisa e na publicação científica. Epidemiol. Serv. Saúde, 26(3):431-432.

INEP (2017). Censo da Educação Superior 2017: notas estatísticas. INEP-MEC, Brasília, DF, Brazil.

Keller, E. F. (2006). Qual foi o impacto do feminismo na ciência? Cadernos Pagu, (27):13-34.

Lopes, M. M. (1998). Aventureiras nas ciências: refletindo sobre gênero e história das ciências naturais no brasil. Cadernos Pagu, (10):345-368.

Louro, G. L. (2004). Gênero, sexualidade e educação: uma perspectiva pós estruturalista. Vozes, Petrópolis, RJ, Brazil.

Matheis, L. (2016). Reflexões sobre a participação de mulheres na ciência a partir de estudos de casos no curso de física da ufrj. CSOnline - Revista Eletrônica de Ciências Sociais, (21):60-83.

Moreira, J. A., Silva, R. M., and Carvalho, M. E. P. (2018). Cenários prospectivos: Uma visão do futuro da presença feminina em cursos de ciência da computação de uma instituição de ensino superior. In Anais do XXVI Workshop sobre Educação em Computação (WEI), Porto Alegre. Sociedade Brasileira de Computação (SBC). 
Nuemberg, A. H. (2005). Gênero no contexto da produção brasileira em Psicologia. Doutorado, Centro de Filosofia e Ciências Humanas - Universidade Federal de Santa Catarina, Florianópolis, SC, Brazil.

Olinto, G. (2011). A inclusão das mulheres nas carreiras de ciência e tecnologia no brasil. Inc. Soc., 5(1):68-77.

ONU (2018). Mulheres e direitos humanos no brasil: avanços e desafios. Direitos Humanos das Mulheres.

Sardenberg, C. M. B. (2002). Da crítica feminista à ciência a uma ciência feminista? In Costa, A. A. A. and Sardenberg, C. M. B., editors, Feminismo, ciência e tecnologia, pages 89-120. REDOR, Salvador.

Schienbinger, L. (2001). O feminismo mudou a ciência? EDUSC, Bauru, SP, Brazil.

Scott, J. (1990). Gênero: uma categoria útil de análise histórica. Educação e Realidade, 16(2):5-22.

Silva, F. F. (2012). Mulheres na ciência: vozes, tempos, lugares e trajetórias. Doutorado, Universidade Federal do Rio Grande, Porto Alegre, RS, Brazil.

Woolf, V. (2018). Duas mulheres. In Woolf, V., editor, Profissões para mulheres e outros artigos femininos. L\&PM, Porto Alegre, RS, Brazil. 